Vol. 11, n² | 2007

Varia

\title{
Garrow and the Detectives: lawyers and policemen at the Old Bailey in the late eighteenth century
}

John Beattie

\section{(2) OpenEdition}

\section{Journals}

Electronic version

URL: https://journals.openedition.org/chs/212

DOI: $10.4000 /$ chs. 212

ISSN: 1663-4837

Publisher

Librairie Droz

Printed version

Date of publication: 1 December 2007

Number of pages: 5-23

ISBN: 978-2-600-01224-9

ISSN: 1422-0857

\section{Electronic reference}

John Beattie, "Garrow and the Detectives: lawyers and policemen at the Old Bailey in the late

eighteenth century", Crime, Histoire \& Sociétés / Crime, History \& Societies [Online], Vol. 11, n² | 2007,

Online since 01 March 2011, connection on 23 March 2022. URL: http://journals.openedition.org/chs/ 212 ; DOI: https://doi.org/10.4000/chs. 212

This text was automatically generated on 22 March 2022.

(c) Droz 


\title{
Garrow and the Detectives: lawyers and policemen at the Old Bailey in the late eighteenth century ${ }^{1}$
}

\author{
John Beattie
}

1 It is often said that the English resisted the reform of the police in the late eighteenth and early nineteenth centuries out of a concern for personal liberty, being willing to accept a certain amount of theft in exchange for freedom from oppression by a central government with too much power ${ }^{2}$. Yet parliament passed a policing act in 1792 that established seven new «public offices» in London that were to be (along with the Bow Street magistrates' office) under the direction of the Home Office. Each of these public offices - or "police offices», as they were also called - was to be led by three salaried magistrates who together were to monopolize the prosecution of crime in the metropolis, outside the City of London; all other justices of the peace and their clerks were henceforth prohibited from receiving fees for conducting business other than the licensing of alehouses. Each of the public offices also included six paid constables whose duty it was to prevent robberies and other felonies, and to apprehend offenders against the peace - duties modelled on those of the so-called runners who had been attached to the public office in Bow Street over the previous forty years and who were largely engaged in apprehending and prosecuting serious offenders. In addition, the act conferred new authority on constables to arrest people they suspected of being thieves, a clause aimed particularly against pickpockets who were thought to ply their trade at the entrances to the theatres and other "places of public resort». Constables were authorized to take such persons before magistrates who could convict them of being «reputed thieves» and commit them to a house of correction for a term of six months at hard labour. In sum, the statute known as the Middlesex Justices Act embodied the most significant changes in London policing before the establishment of the Metropolitan Police in $1829^{3}$.

2 The bill had been opposed in parliament by the Foxite whigs, in part on the grounds that the government's direct control of the new stipendiary magistrates meant an 
increase in patronage and an expansion of the influence of the crown. The opposition also objected to the clause that authorized the arrest and punishment of men and women who were merely suspected of being thieves, an accession of power, Charles James Fox said, that undermined fundamental principles of the Common Law and English justice (The parliamentary history of England, 29, 1178-1183, 1464-1476). None the less, the bill passed without difficulty - and without, apparently, any objections being raised to the appearance in London of close to fifty paid policemen. This was not a large number in a city of a million inhabitants. But in view of the objections that were to emerge when police reform was raised as a serious issue in the years after the French Revolution, the apparently unchallenged acceptance of paid officers in 1792 does raise a question about the public's attitude towards the professional policemen who had been active at the Bow Street magistrates' office over the previous decades.

This is the subject I propose to explore in this essay, and to do so by examining the relationship between policemen and defence counsel at the Old Bailey, the principal criminal court in London, in the decade before the passage of the 1792 act. The police officers I am principally concerned with are the officers who worked under the direction of the magistrates at Bow Street. Groups of similar men attached themselves to a number of magistrates in other parts of the metropolis who, informally and without official support, came together to form so-called «rotation offices» beginning in the 1760s (Paley, 1983, ch. 6). But before 1792, the Bow Street magistrates office was the only such institution in receipt of public money - a government subvention that had enabled Sir John Fielding, the leading magistrate there from 1754 to 1780 , to attract and support a group of officers who could devote themselves to the investigation of offences and the apprehension and prosecution of offenders. The Bow Street office was a centre of policing and prosecution in the second half of the century and its officers - the runners - became well known to the public ${ }^{4}$.

In giving evidence in trials at the Old Bailey, the principal criminal court in London, the runners from time to time encountered defence counsel who were as committed to exposing weaknesses in prosecution cases as the police officers were in winning convictions. In examining their encounters in court in the decade before the passing of the 1792 act, and in particular the way in which defence counsel dealt with men who were frequently in a position to bring damaging evidence against their clients, I hope to uncover evidence of attitudes towards paid policemen in the last decades of the eighteenth century, their credibility as witnesses, and their more general reputation and standing in society.

5 I concentrate on the decade after 1783 because barristers were appearing then as defence counsel much more frequently in old Bailey trials than they had in previous decades, and they were also first identified by name then in the published Proceedings ${ }^{5}$. I am also interested in the work of a lawyer who was active in that decade and was renowned for his aggressive cross-examinations of prosecution witnesses: William Garrow. Garrow took his first case at the Old Bailey in December 1783 and over the next decade appeared in close to a thousand trials, mainly as a defence counsel (Beattie, 1991). His fierce commitment to the interests of his clients makes it certain that if there were weaknesses to be exploited in the credibility of the runners as witnesses he would almost certainly have found them and brought them to the attention of judges and jurors. It is not so much Garrow's own attitude towards the policemen that is important, but rather his judgment of how juries regarded them and thus how he ought 
to treat them if he was to do his best for his clients. My assumption is that Garrow's dealings with the runners who appeared for the prosecution at the Old Bailey over a decade in which he developed a reputation as a bruising cross-examiner provides some evidence of how these police officers were regarded by the craftsmen and shopkeepers and other respectable men of middling status who sat on London juries.

\section{Detectives}

6 The apprehension and prosecution of suspected felons was strengthened in the second half of the eighteenth century by the innovations introduced by Henry and John Fielding in their practice as magistrates in Bow Street, Covent Garden. Their work included the formation of a group of half a dozen paid police officers, supported by assistants and later by patrolmen, who were known to the public initially simply as «Mr Fielding's men» and by the 1770s as the «Bow Street runners». They were established with the financial support of the government, principally to go after the highwaymen and footpads who had brought panic to the streets of London in the crime wave that followed the conclusion of the war of Austrian Succession in 1748. They thought of themselves as public officers, but the runners differed sharply from parish constables and night watchmen who were the principal guardians of their localities. Such men had never been expected to carry on policing duties outside their parishes and wards, certainly not to take initiatives that would involve the pursuit of offenders. That is precisely what the runners had been created to do - to investigate serious criminal offences and in particular to apprehend and help to prosecute the highwaymen and street robbers whose activities caused panic in the capital from time to time.

7 It is anachronistic to call these men detectives: no contemporary used that word. But it is an anachronism worth employing, not only because it helps to distinguish them from the long-established policing forces of London, but also from the «thief-takers» who had become familiar figures in London in the first half of the century. Thief-takers had been known earlier in the seventeenth century, but they became more numerous in the1690s, following the establishment of statutory rewards of $£ 40$ for the conviction of certain serious offenders - including highwaymen, London street robbers, burglars, and coiners. Thief-takers came to be regarded with considerable distaste over the first half of the eighteenth century, largely because so many of them had acted corruptly, framing innocent men or encouraging others to commit offences for which they could be prosecuted and convicted. The Fieldings established their small group of Bow Street men as a counterweight to such men. They would be «real thief-takers», John Fielding said - peace officers who would actually go after the gangs of violent offenders and attempt to bring them to justice ${ }^{6}$.

The Bow Street men were also unlike earlier thief-takers in that they became wellknown to the public. Their activities were regularly reported in the press, and the evidence they gave in trials at the Old Bailey appeared in the printed Proceedings of the court. Those Proceedings, along with the manuscript records of the courts provide us with a sense of the kinds of cases the runners took up, but they are far from revealing the full extent of their work. The runners carried out a range of routine policing tasks under the direction of John Fielding and other Bow Street justices, glimpses of which can be gained from a number of financial accounts submitted to the Treasury (TNA: $T$ 38/671; T 1/387 (1758); T 1/414 (1762); T 1/449 (1766); T 1/454 (1767). A full record even 
of their criminal work cannot be reconstructed from court records, since not all of their investigations resulted in the apprehension of a suspect and of those that did, some must have failed to get to court because of lack of evidence or the unwillingness of victims to prosecute. In addition, the runners also worked for private prosecutors, provincial magistrates, government departments, and corporations like the Bank of England, and some of that work resulted in cases that were prosecuted in courts outside London?

9 The records of trials at the Old Bailey do, however, provide the fullest body of evidence of the engagement of the runners in the investigation and prosecution of felonies in London. There are several relevant sources. In the first place, the runners gave evidence before the Bow Street magistrates in the course of the pretrial process held to determine whether an accused offender would be committed to gaol to await trial. Their depositions, or «informations» as they were called, were supposed to be forwarded to the trial court, along with similar statements given by the victim and his or her witnesses. They served as the basis of the indictment and they were occasionally read in court when there was a dispute about what had actually been said before the justice ${ }^{8}$. Where they have survived - and since they were not part of the formal record of the courts their survival has been haphazard - depositions given by the runners reveal a great deal about their investigations into criminal offences and interrogations of the suspects they arrested. They do not, however, provide an accurate count of the runners' appearances at the Old Bailey: the existence of a deposition does not mean that a trial took place; and, on the other side, a witness could testify in a trial who had not earlier given evidence to the committing magistrate. The unusually large number of depositions that survive for the years 1781-1789 are none the less useful windows into the runners' work, and the fact that eight runners (and others associated with Bow Street) gave close to 200 depositions in those years at least provides some guide as to who among them were the most active officers9.

10 A better guide to the frequency with which the runners testified at the Old Bailey is provided by the indictments, the formal charge against the accused which includes the names of witnesses sworn before the grand jury to give evidence in the case, though they are far from providing a complete account of the runners appearances ${ }^{10}$. These can be usefully supplemented by the Proceedings, though they too only provide a partial record of witnesses' appearances at the Old Bailey. The Proceedings are longer and more detailed in this period than they had ever been, but they were still heavily edited. The publisher left out much procedural detail, shortened the accounts of most trials, and entirely eliminated the evidence given in many of the straightforward larceny cases reducing them to a brief statement of the charge and the jury's verdict. None the less, these imperfect sources - the indictments and printed accounts of he trials - together provide what is likely to be a reasonable indication of the number of times that Bow Street police officers gave evidence in felony trials at the Old Bailey in the last decades of the century.

11 An analysis of the indictments and the Proceedings for twenty-two sessions of the old Bailey between 1770 and 1792 suggests that on average something on the order of eight or nine runners appeared in the witness box in every session. An assistant or a patrolmen (a street patrol having been instituted in 1783) would have done so too, so that about ten men identified with Bow Street appeared in every session, ranging from three in July 1771 to seventeen in July 1774 . On average then, something like two Bow 
Street men appeared in the Old Bailey witness box on every day of a session ${ }^{11}$. These figures without doubt fall short of the actual attendance of the runners, but at the least they confirm that they would have been familiar to the important decision-makers in the court, the high court judges and the recorder of London, who presided over the trials, and the jurors, many of whom would themselves have given service many times in the past. In the decade 1780-1789, a third of the members of the Middlesex trial juries on average had had prior experience on a jury ${ }^{12}$. The evidence of runners' attendances at the old Bailey also confirms the impression derived from the depositions forwarded from Bow Street as to who the most active officers were. They were led by Charles Jealous and John Clarke, who together gave a third of the depositions and testified in a quarter of the indictments in our sample. Other runners prominent on the lists of deponents and witnesses were John Carpmeal, Patrick MacManus, Moses Morant, John Shallard, David Prothero, and John Townsend, who was to become the most famous runner of them all, in part because of his longevity in the office (1783-1832) and because he became a great favourite of George III, acting as his bodyguard for many years.

By the 1780s, many of the Bow Street officers had been in place for several years and were frequently enough in court that they must have become not only used to being there and testifying in public, but also conscious of the most effective way to present evidence. They could also from time to time draw on a store of information compiled by clerks at Bow Street under John Fielding's directions, information about crimes reported and offenders suspected, including a list of the names and addresses of pawnbrokers and other likely receivers, and a so-called «watch book» in which the names of the makers of watches reported stolen were recorded and the numbers they had assigned to the watch - information that led the runners from time to time to highwaymen, street robbers, and pickpockets who had taken expensive watches and who commonly sold or pawned them immediately (TNA: T 38/671, ff. 4, 10; T 1/387, p. 10; T 38/671 p. 28).

\section{Defence counsel}

13 The runners' evidence undoubtedly strengthened the prosecution cases in which they testified and in a decisive way in some. In the courtroom they came into contact with barristers acting as defence counsel who were as committed to defending accused felons as the runners were on the other side. They were also relatively new to the criminal process. Lawyers had not been involved in criminal trials, certainly not in trials of felons, before the second quarter of the eighteenth century. Victims of crimes had always been able to engage counsel to help them present their cases, but defendants were not allowed the same privilege until the 1730s. Then, in the face of more aggressive prosecution that followed the introduction of parliamentary rewards (and a significant supplement to those rewards in the case of robberies in London in the 1720 s by the central government which was increasingly interested in effective prosecution), judges began to allow prisoners to hire barristers to support them in court (Langbein, 2003, pp. 106-177). What these lawyers were able to do for their clients was closely controlled by the bench - controlled because the judges wanted defendants to speak on their own behalf, both as an aid to the jury in coming to their verdict and because in a subsequent pardon procedure the trial judge would almost certainly be 
asked to provide the king with his assessment of a convicted prisoner's character. The judges thus prevented a defendant's lawyer from speaking directly to the jury, to comment on the evidence, or to lay out their client's defence. In effect, defence counsel were allowed only to do what the judges had always done for prisoners on trial: that is, to examine defence witnesses and to cross-examine the victim and his or her witnesses as they presented the evidence for the prosecution. This provided an opportunity for indirect comment and the possibility of casting doubt on the evidence and perhaps undermining the credibility of prosecution witnesses. But a defendant's lawyer remained limited in what he could do in court until the passing of the Prisoners Counsel Act in 1836, which for the first time allowed full defence by counsel for defendants on trial for felonies ${ }^{13}$.

Despite these restrictions, a number of defendants in the 1730s clearly thought it worth their while to engage barristers to help them in court. Over the next forty years, lawyers can be found acting on both sides in felony trials at virtually every session of the court, though never in more than a few cases. Before the last two decades of the century, it would have been very rare for more than five per cent of defendants to have counsel at a session of the Old Bailey. Their numbers were to increase sharply, however, in the 1780s, when as many as a quarter to a third of accused felons sought the help of defence counsel ${ }^{14}$. This may have been in part a response to the aggressive policing and prosecution activities over the third quarter of the century led by Bow Street and that were being taken up in several other «public offices» by the 1780s. The timing of the increase in the number of defence counsel may also have been encouraged by the demobilization of large numbers of soldiers and sailors at the end of the American war in 1782, the conclusion of which was followed by a familiar post-war crime wave and a strongly rising level of executions at Tyburn, the result in part of the king's determination not to pardon anyone convicted of an offence carried out with violence $^{15}$. An apparent tilting of the balance in the courtroom emerging in the 1770 s to the advantage of the prosecution combined with sharply increased levels of execution, may together explain why larger numbers of defendants than ever before sought the help of lawyers at the Old Bailey at the end of the American war.

\section{William Garrow}

15 A changing climate of prosecution may also explain why these barristers began to adopt more aggressive tactics in defence of their clients - taking advantage of the opportunities offered by cross-examination in doing so - and why it was in this period that the characteristic form of the adversarial common law trial took shape (Langbein, 2003, pp. 252-343). The leading proponent of the vigorous defence was a young man who took up practice at the Old Bailey in 1783, William Garrow. He was only twentythree, but Garrow had trained himself for criminal practice while he was a student by regular attendance at the Old Bailey. He had acquired a deep knowledge of the criminal law and plunged in immediately, volunteering in his very first session to act pro bono on behalf of two women who were without counsel. Within months he was being noticed in the press. The sharpness of his mind and power of his speech, his ability to seize on weaknesses in prosecution evidence, his knowledge of the law and skill in elucidating the details and relevant points of leading cases, was to take him to the leadership of old 
Bailey barristers in the 1780s. During the decade in which he was active in that court, he was engaged overwhelmingly for the defence ${ }^{16}$.

Garrow was a domineering and intimidating presence in the courtroom, in large part because of his determined and insistent probing of witnesses who struggled to avoid answering his questions. Judges were occasionally persistent too in seeking answers from a witness who was less than forthcoming. But judges were not likely to insist that recalcitrant witnesses answer questions as strenuously as a lawyer who had been briefed and who was as committed as Garrow to the defence of his clients. Garrow bullied prosecutors into answering questions - occasionally reminding them in capital cases that they had the defendant's life in their hands and pushing them to "give a direct answer», insisting that «I will have an answer to every question I put to you» (OBP, Feb. 1785 (James Wiggan et al.) t17850223-3). He was capable of repeating a crucial question dozens of times, telling one man who ducked and dodged to evade answering a question that «I will repeat it till midnight, till I get an answer.» (OBP, Feb. 1785 (James Wiggan et al.) t17850223-3). From time to time Garrow came into conflict with the bench. «I think these trials ought to proceed with more gravity», Mr Justice Gould observed during a trial in which Garrow's probing and sarcastic questioning of a witness had provoked laughter in the courtroom (OBP, Feb. 1784 (Richard alias Jonas Wooldridge) t17840225-95). But judges put few restraints on the cross-examining tactics of defence counsel since they were doing in principle what the judges themselves might have done. A judge told one prosecutor who objected to Garrow's questions, «if the counsel ask you a question that is not proper, I shall find it my duty to stop him; but you are not competent to judge the propriety of the question» (OBP, Sep. 1789 (William Clark) t17890909-31).

17 Typical of Garrow's style was his assault on an informer who provided the principal evidence against James Frewen and Robert Simmonds, accused of horsetheft in 1785. Frewen had been arrested by Carpmeal and Jealous, Bow Street runners, on the evidence of one Worley Walmslay, who claimed that Frewen had told him he had stolen the horse and had brought it to London from the country and who was obviously angling to collect some part of the reward advertised for the horse's return. Since there was no corroborating evidence, the trial turned on the informer's testimony, and much of the printed report is taken up with Garrow's cross-examination of Walmslay, in which he first attempted to cast doubt on his story by asking him why a man he barely knew had told him he had stolen a horse. Garrow then concentrated on undermining Walmslay's credibility. He got him to admit that he had been convicted of larceny a few months earlier at the Old Bailey, followed with a series of insistent questions designed to make it clear to the jury that Walmslay had been unable to find work as a result of this conviction and had taken up informing as a career. He concluded with a rhetorical question that reminded the jurors, though it was surely unnecessary, why informers in capital cases were so despised: «How much blood money have you had since, my friend?» Frewen was acquitted (OBP, Dec. 1785 (James Frewen and Robert Simmonds) t17851214-117).

\section{Garrow and the detectives}

Garrow was a formidable opponent. He was capable of causing such anxiety in witnesses that one man who had to face him in court was advised to say that he was 
«too feeble» to answer his questions (OBP, July 1786 (William Smith) t17860719-07). It is thus potentially revealing of the standing and reputation of the officers attached to Bow Street and to the other "public» or «rotation» offices that had emerged in the metropolis by the 1780s to consider how Garrow dealt with these men in court. Having undertaken investigations and made arrests, searched and questioned suspects sometimes before the magistrates, and as often in a public house called the Brown Bear directly across Bow Street which they used as a form of police station - the Runners were frequently in a position to add considerable weight to the prosecution in felony trials at the Old Bailey. In property cases - virtually the only offences in which they were likely to give evidence at the Old Bailey - they could often report in depositions and in evidence at a subsequent trial the way investigations had been conducted, what had been found and where, what suspects had said when they were apprehended or when they were examined before the magistrates. They could give effective support to the allegations made by private prosecutors by providing evidence that associated defendants with the stolen goods listed in the indictments.

It is impossible to know how frequently the evidence provided by the Runners led to convictions in cases in which juries might otherwise have acquitted. Juries did not explain their verdicts and one could never be certain what had tipped their decisions one way or the other even if we had complete records of the trials and not just the heavily-edited accounts that make up the printed Proceedings of the old Bailey. Still, there is some reason to think that prosecutions in which the runners contributed evidence about their investigations and searches and their dealings with prisoners had a better chance of bringing a conviction than others. A five year sample of property cases tried at the old Bailey between 1770 and 1790, reveals that in those in which no runner gave evidence the juries found $59 \%$ of the defendants guilty, whereas the equivalent figure when runners were in court to contribute their testimony to the prosecution case was $79 \%{ }^{17}$. There is no way to know that it was the runners' evidence that made the difference, but the figures do at least suggest that as a possibility.

20 Like everyone involved in prosecuting cases in which convictions would bring parliamentary rewards, the Runners were, inevitably, vulnerable to the charge that their evidence was tainted by their financial interest in the outcome of the case. All prosecutors and their witnesses in cases in which convictions brought a substantial state reward were open to such charges, and it was a natural defence tactic in trials of robbers and burglars to remind jurors that prosecutors and their witnesses might well be motivated by the hope of earning «blood money.» It was a tactic that William Garrow was always willing to employ. It was no doubt more effective against some witnesses than others, and Garrow seems to have shaped his cross-examinations of witnesses in accordance with his sense of jurors' own attitudes and biasses.

21 Garrow was hard on thief-takers not attached to Bow Street or one of the rotation offices. He made a distinction between public officers of the law and men he called "private traps», who sought out and prosecuted offenders without being in any way connected to a magistrate. Such men had been common in the first half of the century and there were still thief-takers in the 1780s not employed by the magistrates at Bow Street or not working from one of the rotation offices. Garrow treated such men with open contempt, presumably feeling that the jurors would have little regard for those who were simply in the business for money and who worked without the implicit authority that the runners at the public offices derived from operating under the 
auspices of magistrates. Garrow took a hard line with them when they refused to acknowledge that they stood to gain financially from a conviction. «How long have you been engaged in this honourable business of thief-taking?» he asked Joseph Levy, and then, when Levy denied that he had helped prosecute cases in the previous session, «What, there was no blood money last Sessions?» (OBP, Jan. 1785 (George Norris et al.) t17850112-20). He asked another thief-taker, Christopher Sanders, who was giving evidence in a robbery case in 1792, how often he had been in court, how many rewards he had collected, and whether he had other cases "of the same sort» pending in other courts (he had). Garrow concluded his cross-examination by observing in the form of a question, and for the benefit of the jury, that «you are neither a police officer [that is, a runner] nor a parish officer, but a gentleman having time to do this business», to which Sanders replied lamely «it is for the good of the public» (OBP, Dec. 1792 (Edward Egerton) t17921215-3). That was precisely the point that Garrow intended to deny by his insistent cross-examinations of both private thief-takers and the prosecutors who hired them - cross-examinations aimed at forcing them to admit that they were well aware of the rewards they were looking forward to earning while putting defendants' lives at risk ${ }^{18}$.

When the opportunity arose, Garrow occasionally subjected the Bow Street officers and the men who had attached themselves to the rotation offices to vigorous crossexaminations - and particularly the latter who occupied a more tenuous position in the policing world than the Bow Street men. The magistrates in those offices were not themselves highly regarded; indeed, they were looked down upon as men of indifferent character, who made a trade of the justice business and who were not in a position to exercise the same kind of control over the runners attached to their offices as the Bow Street magistrates ${ }^{19}$. Bow Street had emerged as the most prominent and active centre of policing and prosecution in the metropolis after 1750 because of John Fielding's energy and leadership and because of the government's subvention which gave its magistrates and runners numerous advantages. The three magistrates who shared the work there by the late 1760 s were the only justices in receipt of financial support before the legislation in 1792 created a cadre of stipendiaries ${ }^{20}$. The runners were in a much more advantageous position than the men attached to the rotation offices because their work was rewarded by fees and expences paid in the office. They had a stable income on which they could build from state rewards for the conviction of serious offenders, and from work for government departments and for magistrates around the country, extra work to which, because of Bow Street's prominence, they had more ready access than the men at the rotation offices. The Bow Street public office was better established and more highly regarded in the 1780s than the emerging public offices in other parts of the metropolis. Sir Sampson Wright, the chief magistrate, said in 1783 that its runners were able to earn a «comfortable Livelihood with Reputation to themselves and Benefit to the Public», and that they developed in consequence a sense of group identity - the sense, as Wright went on to say, of being «a sort of Society» (NLI: Ms 15930/1).

These differences in standing and reputation registered in the Bow Street courtroom. Garrow treated the men attached to the magistrates' offices around the metropolis notably more roughly than the runners who worked under the direction of the justices at Bow Street. He was not unwilling to cast doubt on their motives and integrity by calling them thief-takers, and asking them in court how much money they expected to earn from the conviction (and possible execution) of the defendants in the dock. He 
accused them of encouraging victims to charge more serious offences than the facts warranted in the hope of earning rewards, and of extracting confessions by threats or the promise of favours (OBP, Sept. 1784 ((John Lawrence) t17840915-37; Oct. 1786 (John Lightfoot and John Tyrrell) t17861025-16; Dec. 1787 (John M'Carty and Thomas Hartman) t17871212-24; April 1790 (John King) t17900424-16). In cross-examining two such officers - including one he called «a trap belonging to Mr. Staples's office»Garrow asked them repeatedly about the blood money they had earned in recent years, before getting other witnesses to reveal that an officer had planted evidence on one of the accused. The jury acquitted the four defendants (OBP, Jan. 1785 (George Norris et al.) t17850112-20). In another trial, in which most of the evidence concerned the way an officer from the Bloomsbury public office had directed a clerk to draw an indictment for robbery even though it was clear the victim had had his pocket picked in a crowd, Garrow subjected the officer to an aggressive and sarcastic cross-examination, getting him to admit after a series of questions that he was well aware that if the offence had not been charged as a robbery there would be no reward ${ }^{21}$.

The Bow Street officers were vulnerable to these charges, too. But lawyers rarely made much of the fact that the runners stood to gain from rewards in some of the cases they helped to prosecute. «Do you not expect a share of the reward on the conviction of this man?» a lawyer asked Thomas Carpmeal in a robbery case in 1783 that was not going well for the accused. "Yes, you know this as well as you get your own fee», was the reply, and the matter seems to have rested there, presumably because the lawyer recognized that many of the jurors knew the Bow Street men and were not likely to be swayed by being reminded of their interest in the outcome of the case (OBP, Dec. 1783 (James Roberts, alias Yark, and Ruth Mercer) t17831210-2). The Bow Street runners were also open to the suspicion of encouraging victims to lay more serious charges than the facts warranted - as when, for example, a thief and his accomplices took someone's watch in a crowd by shoving or hustling or otherwise distracting the victim. If pushing could be turned into the appearance of violence that put the victim «in fear», the offence might be successfully indicted as robbery and bring all concerned in its prosecution some share of a parliamentary reward. Defence counsel frequently wanted to know in such cases on whose advice the more serious charge had been laid. A prosecution witness, asked by Garrow how the indictment had been drawn, revealed that John Townsend, a Bow Street officer, had had a hand in it. «He is a better lawyer than you», said Garrow; "he knows how to make out a highway robbery» (OBP, April 1787 (John Wheeler) t17870418-96). In another case in which a watch had been stolen without the victim knowing, Garrow asked the prosecutor: «Which of the officers was it that advised you to indict this man for a capital offence» (OBP, May 1786 (Nicholas Waters) t17860531-89). Another prosecutor was asked if he had any conversation with anyone about the indictment and how it was best to charge it, and in particular whether he had spoken with the Bow Street men about sharing the reward. And, he went on, was it at the Brown Bear - the pub across the street from the magistrates' office where it was well known the runners could always be found? Well, yes, it turned out that he «used» the Brown Bear, that he was a regular there. Garrow then got to the point:

Q: So you have heard a great deal about the reward?

A: It was spoke of to be sure.

Q: Who have you had words with about it?

A: Why Mr Atkins, who is here in Court; he is one of the Bow Street officers. 
Q: Have you had conversation with Atkins about it?

A: I have had some little conversation with him, I begged him not to speak of it.

Q: Have you never had any conversation with Townsend?

A: No, Sir, nor nobody else (OBP, July 1787 (Benjamin M'Cowl and George Brace)

t17870711-7). undermine some of the cases they helped to prosecute. But Garrow seems rarely to have treated the Bow Street officers to the kinds of damaging cross-examinations to which he subjected some of the private thief-takers and occasionally the runners from the rotation offices, or indeed any witness who attempted to evade his questions. He did not regard the Bow Street men as beyond criticism. But one finds few examples of his attempting to undermine their credibility by sarcasm or scorn or to shake their testimony by the powerful and insistent cross-examinations that made some witnesses tremble at the thought of having to face him. Indeed, one might characterize his attitude towards them as familiar, occasionally verging on friendly, and at worst neutral. Questioning Charles Jealous about an exchange between a defendant and the magistrate at Bow Street during a pretrial hearing some weeks earlier, Garrow asked if he was sure he remembered that conversation accurately. «If it was for seven years», Jealous replied irrelevantly, «and I saw your face, or any man's face, I could remember him.» To which Garrow said that he had «seen so many instances of your recollecting faces, that I can believe that; but I say as to the conversation?» And when Jealous said that he remembered it well, Garrow left it, not asking him to swear that on oath to unsettle him, as he might have done with another witness (OBP, Feb. 1784 (Thomas Turner) t17840225-97). Garrow engaged in similar exchanges with other runners, on one occasion emphasizing Townsend's long experience when he got him to reveal to the jury that, despite his being indicted under two aliases, his client had never previously been in custody at Bow Street (OBP, Feb. 1786 (John Kitsall, alias Wilmot, aliasSmith) t17860222-55).

Perhaps the most revealing exchanges between Garrow and the Bow Street men came in cases involving counterfeiting of the coinage and in particular in his dealings with one of the runners, John Clarke. Clarke had expert knowledge of the metal trades, having had experience as a silversmith or silver-canehead maker, after an apprenticeship to a button-maker. He had been involved in the prosecution of coining offences on behalf of the Mint for two or three years before becoming attached around 
1770 to the Bow Street office, and he continued to the end of his career in 1793 to be paid by the Mint to prosecute on their behalf. He was to become one of the leading runners, and not simply a specialist in counterfeiting cases. But his knowledge of metal casting and of stamps and dies gave him particular prominence in Bow Street's investigation and prosecution of coining. Over the 1770s and 1780s he emerged as the expert witness in counterfeiting trials - acknowledged as such by judges and lawyers at the Old Bailey, in the assize courts of the Home Circuit, and indeed around the country. Clarke organized Bow Street's raids on suspect coining operations and he was deferred to by the other runners when evidence came to be collected. Coming unexpectedly upon what seemed to be a coining operation, having searched a house for other reasons, Charles Jealous said at the old Bailey trial that followed that «finding something that made us suspect that coining was going forward, we sent for Mr. Clarke; the door was locked; we made no search till Mr. Clarke came» (OBP, Sept. 1776 (Robert Walker) t17760911-56).

It was in court that Clarke's preeminence was most visible and his knowledge most valued. He invariably gave the principal evidence about the function and meaning of the machinery and of the other equipment and materials that had been found, sometimes in the form of a narrative responding to a string of questions or to a request from the bench to "explain to the Court and Jury, the several uses of these things». In both cases the point was to explain the evidence - the machinery and raw materials that had been brought into court and the processes involved in coining (See, for example, OBP, Dec. 1782 (John Johnson and John Lawson) t17821204-78; April 1783 (William Harcourt et al.) t17830430-108; Oct. 1783 (Joseph Lewis) t17831029-68; April 1788 (William James alias Levi et al.) t17880402-48; May 1788 (Jeremiah Grace and Margaret Sullivan) t17880507-30; June 1789 (Thomas Denton and John Jones) t17890603-50); Oct. 1790 (James Royer et al.) t17901027-30). There is no doubt that he became trusted as a witness. And he did so not only because of his expertise, but because of the way he testified in court - by not straining the evidence, not pushing it beyond its limits, or appearing to strive mightily for convictions at any cost. That restraint, along with his careful assembly of evidence and the skill he displayed in presenting it to the jury, explains the persuasive power of his testimony. Clarke gave evidence in just under half of the coining cases tried at the Old Bailey in the twenty years 1774 to 1793 - in 102 out of 210 . In those in which he appeared, the conviction rate was $82 \%$; in the remainder, $40 \%$.

Clarke's reputation at the Old Bailey can be seen in the way Garrow (as well as the judges and other lawyers) dealt with him. Garrow questioned him carefully, and often with a certain respect (OBP, April 1786 (Joseph Yelland et al.) t17860426-9; Sept. 1789 (George Dawson and Deborah Dawson) t17890909-46). In a trial in October 1785, he interrupted Clarke's evidence to raise an objection, saying when he did so that «you are the last man I should stop; but I should object the same if my Lord Mayor was a witness.» Clarke replied - acknowledging Garrow's tenacity in court - «I have not a doubt, Sir, but that you would object to my Lord Mayor.» ${ }^{22}$

\section{Conclusion}

31 Garrow frequently referred to the Bow Street men as officers of justice or officers of the law. In so doing, he recognized the quasi-official position they had come to occupy 
since the middle of the eighteenth century. Despite their reliance on rewards for a good part of their income, the runners had successfully established a public and professional character which owed a great deal to Sir John Fielding's leadership of the office over the quarter century before his death in 1780 . It had been Fielding's ambition to create a centre of policing and prosecution in Bow Street that would encourage the public across the metropolis to report offences and help to diminish crime by ensuring that offenders were apprehended, charged, convicted, and punished. He had persuaded the government to grant stipends to two associate justices who helped him to keep his house in Bow Street open for long and regular hours. He created the first courtroom outside the City of London which attracted and accommodated an audience for his examinations of suspected offenders. And he ensured that Bow Street and the work of his runners would become widely known by inviting the press to report on his pretrial examinations. In these ways, Fielding opened the early stages of criminal prosecution to the public much more than they had ever been before and made Bow Street not only the best known and the busiest magistrates' office in the metropolis, but what was more important, a public institution that continued after his death to be a permanent part of the administration of the criminal law in the capital (Beattie, 2007).

The runners were a crucial element in Fielding's practice of public justice. Under his control and direction - and with the financial support they drew from the government's subvention - they became a stable group of experienced investigators who made detection an acceptable element in policing, and acquired reputations that distinguished them from the shadowy thief-takers who had so corruptly manipulated the opportunities provided by massive state rewards in the first half of the century. The runners were no doubt motivated by the prospect of rewards, and they almost certainly helped to convict men innocent of the charges they faced by rigging identity parades and encouraging hesitant prosecutors. But there seems to have been little perception in the public in the late eighteenth century that the Bow Street men were corrupt or untrustworthy, at least among those in and out of parliament whose opinions were crucial to the shaping of the police, including members of the juries who sat on the felony cases tried at the Old Bailey. This, I presume, is why Garrow made little effort to undermine the runners' credibility as witnesses, whatever his own view of them might have been.

Perhaps the most striking testimony to the reputation of Bow Street and of the runners can be seen in legislation passed by parliament in 1792 known as the Middlesex Justices Act $^{23}$. The bill, which was moved at second reading by Henry Dundas, secretary of state for the Home Department, was designed principally, he said, «to correct abuse in the conduct of trading justices» by creating seven public offices at which three stipendiary magistrates would be empowered, along with Bow Street, to conduct the prosecution of criminal offences in the metropolis. Magistrates outside these offices would henceforth be forbidden to take fees, except those for licencing taverns. Dundas's main interest seems to have been to respond to the constant criticism of the Middlesex and Westminster magistrates, many of whom were perceived to be men of low social standing who misused their authority in order to increase their incomes from fees (Parliamentary History, 29, col. 1179). The bill as Dundas presented it simply offered a plan to create stipendiary magistrates working in a number of public offices. But William Mainwaring, the member of parliament for Middlesex, and a man with an intimate knowledge of the strengths and weaknesses of criminal administration in the 
metropolis, intervened early in the proceedings to ensure that these magistrates would have staffs of paid constables. Mainwaring had been chairman of the Middlesex and Westminster quarter sessions since 1781 . He had seen all the magistrates at work, including those at the rotation offices; he knew the active constables and had heard their testimony at numerous quarter sessions trials over the previous decade. He called on this «local knowledge», as he said, to suggest ways in which the bill as presented could more effectively improve the policing of the metropolis.

Mainwaring was an admirer of Bow Street. When the bill was presented he said that "he wished to know if it was intended, that the offices were to be on the plan of that in Bow-street; how far they were to differ from it, or the reasons for that difference.» If the secretary had in mind creating a number of offices on the model of Bow Street, with magistrates and officers supported by public funds, he went on, «he should in that respect like them» (Parliamentary History, 29, col. 1179). He praised the work not only of the Bow Street runners but of the men attached to the rotation offices that had become important centres of policing by the 1780s. Such men had been to his knowledge «very active in apprehending depredators of the public peace. He should be glad to know, if any of the New Offices were to be attended by such officers» (General Evening Post, 18 April 1792). He pressed further at the committee stage, arguing that the bill «contained nothing which gave personal security to the inhabitants. The Justices had no means by it of enforcing the execution of the law.» Invited at that point by Dundas to suggest a remedy, Mainwaring obliged with a clause stipulating that the magistrates at the new public offices were to employ «constables who were to have certain wages [and] reimbursement of any extraordinary expences» (Gazetteer, 4 May 1792).

In addition, also at Mainwaring's urging, another clause was inserted in the bill at the committee stage that broadened constables' powers of arrest by authorizing them to take up anyone they merely suspected of being a thief and to bring them before a magistrate where they could be punished under the vagrancy laws. This aroused considerable opposition. The Foxite whigs rallied strongly against a clause that, they argued, put citizens at the arbitrary mercy of the police. Lord North said that the problem of petty crime in London was certainly troublesome, but it was «not so alarming as to authorize Parliament in entrusting the dictatorial power into the hands of Messrs. Townsend and Macmanus» - two Bow Street runners, whose names North could assume were well known to members of parliament (Parliamentary History, 29, col. 1474; Gazetteer, 24 May 1792). Other leading members of the opposition, including Charles James Fox, spoke strongly against this proposal. Dundas said in reply that he had consulted some of the Bow Street runners on the issue - expecting, presumably, that their opinion would carry some weight in the matter - and in particular had had «a long conversation with Mr. Macmanus, who assured him that without such powers he could not disperse the dangerous combinations of those who made a trade at pickpocketing» (Parliamentary History, 29, col. 1473; Gazetteer, 24 May 1792). The clause remained in the bill.

The opposition also contended that the creation of salaried magistrates in London was a dangerous precedent that could easily spread to other towns and significantly increase the patronage of the crown - the corrupting character of which had been a whig rallying cry for two decades. The legislation was thus strongly resisted on several grounds. But it is notable that nothing was apparently said in debate about problems posed by an increase in paid constables. No alarms were raised about government 
agents; no charges were made that the government intended to create a police on the French model - the police of Paris being widely believed in England to employ dozens of spies and informers and to wield oppressive powers. Mainwaring's argument was apparently accepted without a murmur that paid officers dedicated to the investigation and apprehension of felons were required if dangerous offenders were going to be caught and punished, since private thief-takers (he reminded the house) had proved to be mainly corrupt and «never touched a thief till he was worth their taking» (The Times, 4 May, 1792).

Bow Street provided the model for the seven new centres of prosecution and policing established in 1792. The changes embodied in the act can be seen as the culmination of a century of policing developments. The 1792 legislation came exactly a hundred years after the first reward statute had offered 40 pounds for the conviction of a highwayman, a statute that set in train the rage of private thief-taking and introduced an entirely new element in the prosecution of felonies. The disastrous effects of uncontrolled thief-taking, all too evident over the first half of the eighteenth century, lay behind the efforts of Henry and John Fielding to establish more honest and more public policing practices. The 1792 act was a testimony to the success of those efforts, in particular John Fielding's transformation of Bow Street into a prominent centre of policing and prosecution. Fielding's innovations were addressed to the problems that seemed most pressing in the middle decades of the eighteenth century.

When police reform and the nature of policing came to be debated in the early nineteenth century, in particular in the years before the creation of the Metropolitan Police in 1829 , the issues to be faced were perceived as entirely different. The old solutions - the detection and prosecution that had been at the heart of the Bow Street enterprise - were clearly no longer acceptable and were abandoned in favour of preventive strategies built around the long-established night watch and constabulary (Reynolds, 1998). Bow Street was then thought to be no longer relevant. But it had been at the centre of London policing for a very long time - not as a failed attempt to create the Metropolitan Police as that emerged after 1829, but as an eighteenth-century solution to eighteenth-century problems.

\section{BIBLIOGRAPHY}

Armitage, G., The history of the Bow Street runners, 1729-1829, London, Wishart, 1932.

Babington, A., A house in Bow Street: crime and the magistracy, 1740-1881,London, MacDonald, 1969.

Beattie, J., Crime and the Courts in England (1660-1800), Princeton, Princeton University Press, 1986.

Beattie, J., London juries in the 1690s, in Cockburn, J., Green, T. (eds), Twelve good men and true: the criminal trial jury in England, 1200-1800, Princeton, Princeton University Press, 1988, pp. 214-253.

Beattie, J., Scales of justice: defense counsel and the English criminal trial in the eighteenth and nineteenth centuries, Law and History Review, 1991, 9, pp. 236-247. 
Beattie,J., Policing and punishment in London, 1660-1750: urban crime and the limits of terror, Oxford, Oxford University Press, 2001.

Beattie, J., Early detection: the Bow Street runners», in Emsley, C., Shpayer-Makov, H. (eds), Police detectives in history 1750-1950, London, Ashgate, 2006, pp. 15-32.

Beattie J., Sir John Fielding and public justice: the Bow Street magistrates court, 1754-1780, Law and History Review, 2007, 25, Spring, pp. 61-100.

Cockburn, J.S., Green, T.A. (eds), Twelve good men and true: the criminal trial jury in England, 1200-1800, Princeton, Princeton U.P., 1988.

Cox, D., 'A certain sense of low cunning': the provincial use and activities of the Bow Street runners, 1792-1839», Eras, 2003, 5[on-line journal: www.arts.monash.edu.au/eras].

Devereaux, S., The condemned of the Old Bailey, 1714-1837: some statistical perspectives, (forthcoming).

Emsley, C., The English police: a political and social history, $2^{\text {nd }}$ ed., London, Longman, 1996.

Hay, D., The class composition of the palladium of liberty: trial jurors in the eighteenth century, in Cockburn, J.S., Green, T.A. (eds), Twelve good men and true: the criminal trial jury in England, 1200-1800, Princeton, Princeton U.P., 1988, pp. 305-357.

Hay, D., Snyder, F. (eds), Policing and prosecution in Britain, 1750-1850, Oxford, Oxford University Press, 1989a.

Hay, D., Snyder, F. (eds), Using the criminal law, 1750-1850: policing, private prosecution, and the state', in Hay, D., Snyder, F. (eds), Policing and prosecution in Britain, 1750-1850, Oxford, Oxford University Press, 1989b, pp. 3-52.

King, P., 'Illiterate plebeians, easily misled': jury composition, experience, and behavior in Essex, 1735-1815, in Cockburn, J.S., Green, T.A. (eds), Twelve good men and true: the criminal trial jury in England, 1200-1800, Princeton, Princeton U.P., 1988, pp. 254-304.

King, P., Crime, justice, and discretion in England 1740-1820, Oxford, Oxford University Press, 2000.

Landau, N., The trading justice's trade», in Landau, N. (ed.), Law, Crime and English Society, 1660-1830, Cambridge, Cambridge University Press, 2002, pp. 46-70.

Langbein, J., The origins of adversary criminal trial, Oxford, Oxford University Press, 2003.

May, A., The bar and the Old Bailey, 1750-1850, Chapel Hill, University of North Carolina Press, 2003.

Paley, R., The Middlesex Justices Act of 1792: Its origins and effects, Ph.D thesis, University of Reading, 1983.

Paley, R., Thief-takers in London in the age of the McDaniel gang, c. 1745-54, in Hay, D., Snyder, F. (eds), Policing and Prosecution in Britain, 1989a, pp. 301-342.

Paley, R., ‘An imperfect, inadequate and wretched system'? Policing London before Peel, Criminal Justice History, 1989b, 10, pp. 98-102.

Palmer, S., Police and protest in England and Ireland, 1780-1850, Cambridge, Cambridge University Press, 1988.

Philips, D., 'A new engine of power and authority': the institutionalization of law-enforcement in England 1780-1830», in Gatrell, V. A. C., Lenman, B., Parker, G. (eds), Crime and the law. The social history of crime in Western Europe since 1500, London, Europa Publications, 1980, pp. 155-189. 
Pringle,P., Hue and cry: the story of Henry and John Fielding and their Bow Street runners, London, William Morrow, 1955.

Radzinowicz, L., A History of English Criminal Law and its Administration from 1750, vol. 2, London, Macmillan, 1957a.

Radzinowicz, L., A History of English Criminal Law and its Administration from 1750, vol. 3, London, Macmillan, $1957 \mathrm{~b}$.

Reynolds, E., Before the Bobbies. The Night Watch and Police Reform in Metropolitan London, 1720-1830, London, Macmillan, 1998.

The parliamentary history of England, 1792, vol. 29.

Wales, T., Thief-takers and their clients in later Stuart London, in Griffiths, P., Jenner, M. (eds), Londinopolis: essays in the cultural and social history of early-modern London, Manchester, Manchester University Press, 2001, pp. 67-84.

Archives

BL: The British Library. Additional manuscripts (Add Mss).

London Metropolitan Archive: Old Bailey ms court records.

NLI: National Library of Ireland

TNA: The National Archives. Treasury Papers (T); Assize records (ASSI).

\section{NOTES}

1. I am grateful for financial support to the Centre of Criminology, University of Toronto, and for research assistance to Erica Charters, Daniel Remick, and Yen Tran. John Beattie is University Professor Emeritus of History and Criminology at the University of Toronto. He is the author of Crime and the Courts in England, 1660-1800 (Princeton and Oxford, 1986) and Policing and Punishment in London, 1660-1750 (Oxford, 2001). He is currently studying the Bow Street runners and the policing of London between 1750 and 1839.

2. Emsley (1996, pp. 21-22); Hay, Snyder (1989, pp. 33-34); Palmer (1988, pp. 19-20, 71-73); Philips (1980, pp. 171-174).

3. Radzinowicz (1957a, pp. 188-194); Radzinowicz (1957b, pp. 123-134); Paley (1983).

4. Emsley (1996, ch. 1); Beattie (2006); Radzinowicz (1957a, pp. 171-187); Radzinowicz (1957b, pp. 29-22); Cox (2003); Armitage (1932); Babington (1969); Pringle (1955).

5. Accounts of trials at the Old Bailey were published in pamphlet form after the eight annual sessions of the court under the title, The Proceedings at the Sessions of the Peace, and Oyer and Terminer, for the City of London, and on the King's Commission of Gaol-Delivery of Newgate, held in JusticeHall in the Old-Bailey for the City of London and County of Middlesex... followed by the date. In citing these trials, I refer to the digitized version available on-line at www.oldbaileyonline.org. I follow the editors' suggested citation guide: OBP, date of session, name(s) of accused, reference number of the trial.

6. Beattie (2001); Wales (2001); Paley (1989a).

7. For the runners giving evidence in the assize courts in the counties near London, see TNA: ASSI/94/1059-62, 1124-1127, 1329-1335, 1258-1261; King (2000, p. 78).

8. Langbein (2003, pp. 40-47, 273-277); Beattie (2007).

9. London Metropolitan Archive: OB/SP/1781-9. Unfortunately, many of these sessions papers are in poor condition, and a significant number of depositions remain «unfit for production.» I have no doubt that my estimates of the number of depositions given by the runners will have to be revised when the damaged documents are repaired and made available for inspection. 
10. The indictments are included in the sessions rolls of the court (London Metropolitan Archive: $\mathrm{OB} / \mathrm{SR} /$ number, year and month). The indictments cannot provide a complete account of witnesses' appearances in court because not everyone listed as having been sworn before the grand jury was called to testify before the trial jury; and some of the bills of indictment were in any case declared to be ignoramus by the grand jury and so did not go forward to trial. Nor was it necessary to testify before the grand jury to give evidence in the trial itself. Recognizances that bound over prosecutors and witnesses to appear to give evidence at a trial are also preserved in the sessions rolls. They, too, provide evidence of the runners' appearances at the Old Bailey, but, again, not every runner who testified in court had been bound over to do so. Of the thirteen runners who gave evidence at the February 1784 session, for example, only seven had entered into recognizances (OB/SR/226).

11. My estimate that there were 5.4 trial days in sixteen sessions between 1771 and 1775 is based on the dates given in the forematter of the Proceedings - counting one of the days of the session as a non-trial day, that is, a day taken up with preliminaries and sentencing. After 1775, it is not possible to learn how long the sessions lasted, since the Proceedings give the dates as that of the opening day «and the following days».

12. Beattie (1988); Hay (1988); King (1988).

13. Langbein (2003); May (2003); Beattie (1991).

14. May (2003, pp. 33-63); Beattie (1991, pp. 226-230).

15. Beattie (1986, p. 583); Devereaux ( forthcoming).

16. May (2003, p. 40-42); Beattie (1991). OBP, Jan. 1785 (George Norris et al.) t17850112-20; OBP, Dec. 1783 (Sarah and Mary Wood) t17831210-44); London Chronicle, 15 Dec. 1784. For examples of the way Garrow demonstrated his knowledge of the criminal law in court, see his elucidation in the trial of James Boston in April 1785 of the issues involved in the Mcdaniel case in 1754, in which a gang had set up two young men to commit a highway robbery in order to convict them for the reward (OBP, t17850406-70); his argument with respect to the felony of returning unlawfully from transportation (OBP, Sept. 1785 (John Henry Aikles) t17850914-181; his argument about the meaning of the statutory law of uttering counterfeit coins in OBP, Feb. 1784 (Richard alias Jonas Wooldridge) t17840225-95.

17. Based on the OBP for $1770,1775,1780,1785$, and 1790 . Only $5 \%$ of the 3645 defendants on trial in these years had to answer evidence presented by the runners.

18. In another such case in 1788 in which three men were charged with robbing a fisherman on the Edgware Road as he was going to market at four in the morning, the victim had gone immediately to the house of a publican, Joseph Herrington, who set out with two other men to chase and eventually catch the three alleged robbers and take them before a magistrate. Garrow's long and insistent cross-examinations forced the prosecutor to admit that he knew that the potential reward was $£ 120$ and that he had discussed this with Herrington, who, Garrow also brought out in cross-examination, had arrested several alleged robbers in recent years, at least three of whom had been hanged. OBP, May 1788 (John Wood, John Cobcroft, and William Fubbs, alias Fielder) t17880507-45.

19. Landau (2002); Paley (1989b).

20. The exception was Saunders Welch. A close friend of Henry Fielding, Welch had been appointed to the Westminster bench soon after the latter's death in 1754. He and John Fielding quarrelled over Welch's demand that they share the work of the office and the stipend equally, and he set up his own magistrates' office in Lichfield Street with the support of a government subvention, which he continued to enjoy. BL: Add Mss 32862, f. 375; Add Mss 32874, f. 379.

21. OBP, Dec. 1787 (John M'Carty and Thomas Hartman) t17871212-24. In a case in which a man had first been charged with fraud but at a second examination before a magistrate found the charge changed to robbery, Garrow's cross-examination of officers - Treadway, «a thief-taker, attending the [rotation] office», and Scandling, a parish patrolman - revealed their role in 
persuading the victim to change her plea. OBP, Feb. 1790 (William Casey) t17900224-83. For other cases revealing Garrow's occasionally aggressive attitude towards officers from the rotation offices, see Sept. 1789 (William Clark) t17890909-31; Sept. 1789 (Henry Todd) t17890909-65.

22. OBP, Oct. 1785 (James Scott et al.) t17851019-45. Perhaps the clearest testimony to Clarke's reputation came in a trial in 1789 when, being questioned by Garrow, he said that he wished to go out of court, no doubt to visit the necessary house, and promised that «I will not speak to anybody I assure you.» The printer of the Proceedings thought it worth reporting the following exchange:Mr. Garrow. I can trust you; but for the satisfaction of the prisoners, whose lives are at stake; you say you will not speak to anybody.Mr. Clark, to the Prisoners, Gentlemen, will you trust me, I will not say anything to any person.Prisoner John Jones. You have too much honour to do anything of the kind Mr.Clark, we are sensible. (OBP, June 1789 (Thomas Denton and John Jones) t17890603-50.

23. 32 Geo III, c. 53. A bill similar in intent though more radical in its proposals had been rejected in 1785 , largely because it had sought to include the City of London in a metropolitan-wide scheme and thereby aroused the powerful and irresistible opposition of the corporation of London, which cherished its independence and self-government under its ancient charter. For the act of 1792 and the development of the rotation offices in the metropolis in the three preceding decades, see Paley (1983).

\section{ABSTRACTS}

The article investigates the reputation of the Bow Street runners, the group of quasi-official police officers established at the Bow Street magistrates court by Henry and John Fielding in the second half of the eighteenth century. In particular, the essay studies the confrontation in trials at the old Bailey in the 1780s between these police officers and one of the most aggressive defence counsel of the period, William Garrow, and compares their treatment with the way Garrow dealt with private thief-takers and other officers. The evidence suggests that the professional police detectives based at Bow Street enjoyed a relatively good reputation, and the essay concludes with the suggestion that this good reputation meant that when seven police offices on the model of Bow Street were established by parliament in 1792 there were no objections that each was given a similar staff of six paid detective constables. Unlike the police established in London in 1829, which was devoted to defeating crime by surveillance, the eighteenth century solution to the crime problem of the capital was detection and prosecution.

Cet article examine la réputation des «Bow Street Runners ", unité de policiers quasi-officiels mise en place par Henry et John Fielding auprès du tribunal de Bow Street dans la deuxième moitié du XVIII siècle. Il s'agit plus particulièrement d'étudier la confrontation, au cours des procès tenus à l'old Bailey dans les années 1780 , entre ces policiers et l'un des plus agressifs avocats de la défense de l'époque, William Garrow, et de comparer le traitement qu'il leur réservait avec celui qu'il réservait aux chasseurs de primes et aux autres officiers. Les données donnent à penser que les enquêteurs de Bow Street jouissaient d'une assez bonne réputation et l'article suggère en conclusion que cette dernière explique qu'il n'y eut pas d'objections à doter de six policiers enquêteurs rémunérés chacun des sept bureaux de police établis par le Parlement en 1792 sur le modèle de Bow Street. À la différence de la police créée à Londres en 1829, qui 
visait à combattre la criminalité par la surveillance, la solution élaborée pour la capitale au XVIII siècle s'appuyait sur la détection et la poursuite des infractions.

\section{AUTHOR}

\section{JOHN BEATTIE}

Department of History, University of Toronto, Toronto ON, Canada M5S 3G3,

j.beattie@sympatico.ca 